\title{
GAMBARAN PENGETAHUAN PETUGAS KESEHATAN TERHADAP HEPATITIS B DI RSUP PROF. R. D. KANDOU MANADO
}

\author{
${ }^{1}$ Elia A.P. Hutapea \\ ${ }^{2}$ Adrian Umboh \\ ${ }^{2}$ Rocky Wilar \\ ${ }^{2}$ Novie H. Rampengan
}

\author{
${ }^{1}$ Kandidat Skripsi Fakultas Kedokteran Universitas Sam Ratulangi Manado \\ ${ }^{2}$ Bagian Ilmu Kesehatan Anak Fakultas Kedokteran Universitas Sam Ratulangi Manado \\ Email: User_eliahutapea5@gmail.com
}

\begin{abstract}
Hepatitis is the process of inflammation and or necrosis of liver tissue that can be caused by infections, drugs, toxins, metabolic disorders, and autoimmune disorders. Hepatitis is a world problem as it attacks billion of people, especially in developing countries. Based on Indonesia's Health Profile, the coverage of hepatitis B immunization in Indonesia is around $59.19 \%$, but the incidence of hepatitis $\mathrm{B}$ in various areas is still growing every year. WHO states that, Indonesia is included in a group with moderate and severe epidemic. Wiharta and friends reports that in Jakarta, there is 1 in 20 pregnant women that has positive HBsAg and the sufferer has high infectiousness. It requires proper knowledge of public health from the officers such as doctors, nurses, and co-ass to reduce the number of mortality due to these diseases. The purpose of this study is to acknowledge the comprehension description of health officers and it's relation to education, training, and work experience at Prof. R. D. Kandou hospital, Manado. Methods: This study is conducted using a cross sectional design with observational approach, in this case it is done by observation and questionnaires. Data analysis used in this study is univariate analysis. Samples of 60 people. Results: In the results obtained from 60 health officers, there are 56 people of them have good knowledge on hepatitis B. As for the other health officers with sufficient knowledge on Hepatitis B consists of 4 people. Conclusion: Health officers at Prof. R D Kandou hospital have a good knowledge on hepatitis $\mathrm{B}$.
\end{abstract}

Keywords: Knowledge, Hepatitis B, Health Officer, Mortality.

\begin{abstract}
Abstrak: Hepatitis adalah proses terjadinya inflamasi dan atau nekrosis jaringan hati yang dapat disebabkan oleh infeksi, obat-obatan, toksin, gangguan metabolik, maupun kelainan autoimun. Hepatitis adalah masalah dunia karena menyerang miliaran manusia, terutama di negara berkembang.Berdasarkan Profil Kesehatan Indonesia, cakupan imunisasi hepatitis B di Indonesia sebesar 59,19\%, namun angka kejadian hepatitis B di berbagai daerah masih meningkat setiap tahunnya. WHO menyatakan bahwa, Indonesia termasuk kelompok daerah dengan epidemisitas sedang dan berat. Wiharta dkk. melaporkan, di Jakarta 1 di antara 20 ibu hamil mengandung HBsAg positif dan pengidap tersebut mempunyai daya tular tinggi. Untuk itu diperlukan pengetahuan dari petugas kesehatan seperti dokter umum, perawat, dan co-ass untuk menekan angka morbilitas dari penyakit ini. Tujuan dari penelitian ini adalah untuk mengetahui gambaran pengetahuan petugas kesehatan dan hubungan penegtahuan petugas kesehatan yaitu tentang pendidikan, pelatihan, dan pengalaman kerja di RSUP Prof. R. D. Kandou Manado. Metode: Penelitian ini dilakukan dengan menggunakan desain cross sectional dengan pendekatan observasional, dalam hal ini dilakukan dengan pengamatan dan pengisian kuesioner. Analisis data yang digunakan adalah analisis univariat. Sampel berjumlah 60 orang. Hasil: Darihasilyang didapatkan dari 60 orang petugas kesehatan terdapat 56 orang yang memiliki pengetahuan baik tentang Hepatitis B. Sedangkan untuk petugas kesehatan dengan penegetahuan yang cukup terhadap Hepatitis B berjumlah 4 orang. Simpulan: Petugas kesehatan di RSUP Prof. R.D.Kandou memiliki pengetahuan yang baik terhadap penyakit Hepatitis B. Kata kunci: Pengetahuan, Hepatitis B, Petugas Kesehatan, Morbilitas.
\end{abstract}


Hepatitis adalah proses terjadinya inflamasi dan atau nekrosis jaringan hati yang dapat disebabkan oleh infeksi, obat-obatan, toksin, gangguan metabolik, maupun kelainan autoimun. $^{1}$ Ketikapertama kaliterinfeksi, infeksi pada orang tersebut dapat berkembang menjadiinfeksiakut, yang bisa menyebabkan infeksi kronis, yang dimulai dari infeksiyang sangatringan, dengansedikit atau tanpa gejala, sampai menyebabkankondisi yang serius danyang membutuhkan rawat inap. ${ }^{2}$

Hepatitis adalah masalah dunia karena menyerang miliaran manusia, terutama di negara berkembang. Terdapat sekitar 216 juta manusia sebagai karier dan terancam kena kanker hati di kemudian hari. ${ }^{3}$

WHO menyatakan bahwa, Indonesia termasuk kelompok daerah dengan epidemisitas sedang dan berat. Wiharta dkk. melaporkan, di Jakarta 1 di antara 20 ibu hamil mengandung HBsAg positif dan pengidap tersebut mempunyai daya tular tinggi. Frekuensi HBsAg pada anak dilaporkan 9,71\% dan di Nusa Tenggara Barat dilaporkan sekitar 18,8\% pada anak usia 10 - 14 tahun. $^{3}$

Berdasarkan Profil Kesehatan Indonesia, cakupan imunisasi hepatitis B di Indonesia sebesar 59,19\% (Depkes RI). Namun angka kejadian hepatitis B di berbagai daerah masih meningkat setiap tahunnya, seperti di Sumatera Utara angka kejadian hepatitis B pada tahun 2008 sebanyak 48 kasus, sedangkan pada tahun 2009 meningkat menjadi 64 kasus. Menurut penelitian Helmi dkk. menyebutkan ada hubungan antar faktor internal (pengetahuan dan tingkat pendidikan) dan faktor eksternal (peran petugas kesehatan) dalam pemberian imunisasi Hepatitis B. ${ }^{4}$

\section{METODE PENELITIAN}

Penelitian ini bersifat deskriptif dengan design penelitian cross sectional yang dilaksanakan pada bulan November 2013 sampai Januari 2014. Populasi dalam penelitian ini adalah petugas kesehatan di RSUP Prof. Dr. R. D. Kandou Manado. Pengambilan sampel menggunakan kuesioner. Kriteria inklusi adalah petugas kesehatan RSUP Prof. Kandou dan bersedia menjadi responden.

Untuk mengukur pengetahuan petugas kesehatan, instrument penelitian yang akan digunakan adalah kuesioner. Pengisian kuesioner tentang Hepatitis B dilakukan olehpetugas kesehatan di RSUP Prof. Kandou kota Manado.

Data dianalisa dengan SPSS (versi 17) dengan menggunakan analisa scoring. Berdasarkan hasil penelitian kemudian hasilnya diinterpretasikan pada kriteria: pengetahuan baik (76-100\%), pengetahuan sedang (56-75\%), pengetahuan kurang (40$55 \%)$, pengetahuan buruk ( $<40 \%)$.

\section{HASIL PENELITIAN}

Penelitian dilakukan di RSUP Prof. Kandou kota Manado dengan jumlah sampel 60 orang petugas kesehatan yang terbagi dari 20 orang Co-Ass, 20 orang Perawat, dan 20 orang dokter umum.

Tabel 1. Gambaran pengetahuan petugas kesehatan terhadap Hepatitis B

\begin{tabular}{lll}
\hline Pengetahuan & Jumlah (n) & Persen (\%) \\
\hline Baik & 56 & $93,3 \%$ \\
Cukup & 4 & $6,7 \%$ \\
Total & 60 & $100 \%$ \\
\hline
\end{tabular}

Pada Tabel 1 dapat dilihat bahwa pengukuran tingkat pengetahuan petugas kesehatan terhadap penyakit Hepatitis B melalui kuesioner menunjukkan 56 orang responden memiliki pengetahuan yang baik, dan 4 orang responden dengan pengetahuan yang cukup.

Pada Tabel 2 dapat dilihat bahwa petugas kesehatan RSUP Prof. Kandou yang bekerja sebagai dokter umum, dokter muda, dan perawat memiliki pengetahuan yang baik terhadap Hepatitis B, dengan jumlah responden pada dokter umum yaitu 20 orang yang memiliki pengetahuan yang baik (33,3\%), untuk dokter muda dengan jumlah responden yaitu 20 orang, didapatkan 17 orang yang memiliki pengetahuan yang baik $(28,3 \%)$ dan 3 orang yang memiliki penge- 
Hutapea, Umboh, Wilar, Rampengan; Gambaran Pengetahuan Petugas Kesehatan...

Tabel 2. Gambaran pengetahuan petugas kesehatan terhadap Hepatitis B berdasarkan status pekerjaan

\begin{tabular}{lcccccc}
\hline $\begin{array}{l}\text { Status } \\
\text { Pekerjaan }\end{array}$ & \multicolumn{7}{c}{ Tingkat Pengetahuan } \\
\hline & \multicolumn{2}{c}{ Baik } & \multicolumn{2}{c}{ Cukup } & \multicolumn{2}{c}{ Total } \\
\hline & $\mathrm{N}$ & $\%$ & $\mathrm{~N}$ & $\%$ & $\mathrm{~N}$ & $\%$ \\
\hline Dokter umum & 20 & 33,3 & 0 & 0 & 20 & 33,3 \\
Dokter Muda & 17 & 28,3 & 3 & 5 & 20 & 33,3 \\
Perawat & 19 & 31,67 & 1 & 1,67 & 20 & 33,3 \\
Total & 56 & 93,3 & 4 & 6,67 & 60 & 100 \\
\hline
\end{tabular}

tahuan yang cukup (5\%), untuk perawat dengan jumlah responden yaitu 20 orang, didapatkan 19 orang yang memiliki pengetahuan yang baik $(31,67 \%)$ dan 1 orang yang memiliki pengetahuan yang cukup $(1,67 \%)$.

\section{BAHASAN}

Hasil penelitian yang dilakukan pada 60 orang petugas kesehatan di RSUP Prof. Kandou didapatkan petugas kesehatan yang memiliki tingkat pengetahuan yang baik yaitu 56 orang $(93,3 \%)$ dan untuk tingkat pengetahuan yang cukup yaitu 4 orang (6,7\%) (tabel 2.1). Hasil penelitian ini berbeda dengan hasil penelitian Oi Ka Chan dkk,pada petugas kesehatan di Cina, didapatkan $27 \%$ dari $75 \%$ subyek yang diteliti diketahui mempunyai pengetahuan yang baik, sedangkan $60 \%$ dari $75 \%$ subyek yang diteliti mempunyai pengetahuan yang cukup tentang infeksi HBV. ${ }^{5}$

Pengetahuan yang baik didukung juga dengan beberapa faktor yang antara lain pendidikan, pelatihan, informasi dan pengalaman. ${ }^{6}$

Pada penelitian yang dilakukan pada 60 orang petugas kesehatan di RSUP Prof. DR. R.D. Kandou, didapatkan sebagian petugas kesehatan yang tidak mengikuti pelatihan Hepatitis B sekitar 96,7\% yang memiliki pengetahuan yang baik sedangkan yang mengikuti pelatihan Hepatitis B hanya 3,3\% yang memiliki pengetahuan yang baik (tabel 2.4). Dan sebagian petugas kesehatan yang tidak mengikuti pelatihan Hepatitis B dengan tingkat pendidikan DIII dan DIV sekitar 8,3\% memiliki tingkat pengetahuan yang baik, dan untuk tingkat pendidikan S1 sekitar 25\% yang mempunyai tingkat pengetahuan yang baik, sedangkan tingkat pendidikan dokter umum sekitar 53,3\% memiliki pengetahuan yang baik (tabel 2.6), sehingga menunjukkan bahwa pengetahuan petugas kesehatan banyak didapatkan melalui pengalaman kerja di rumah sakit dan juga melalui pendidikan formal, yaitu pendidikan di sekolah kesehatan, sehingga tidak terbatas pada pendidikan non formal saja, seperti pelatihan-pelatihan.

Dari hasil ini menunjukkan adanya hubungan teori konsep dasar pengetahuan, yang berarti petugas kesehatan di RSUP Prof Kandou tidak hanya tahu, tapi juga memahami tentang penyakit Hepatitis B, dan ada aplikasi langsung pada pasien Hepatitis B.

Hal ini dikaitkan dengan penelitian pada petugas kesehatan di RSUP Prof. Dr. R.D. Kandou, yang mempunyai pengalaman kerja $<5$ tahun sekitar 68,3\% memiliki pengetahuan yang baik, sedangkan petugas kesehatan yang mempunyai pengalaman kerja 5-10 tahun sekitar 10\% memiliki pengetahuan yang baik, dan untuk petugas kesehatan yang mempunyai pengalaman kerja $>10$ sekitar $15 \%$ memiliki pengetahuan yang baik (Tabel 2), sehingga pengalaman dan pendidikan juga mempengaruhi tingkat pengetahuan seseorang.

Dari hasil ini juga menunjukkan bahwa petugas kesehatan yang telah bekerja 5-10 tahun dan >10 tahun di RSUP Prof. R.D. Kandou, hanya sedikit yang memilki pengetahuan baik terhadap Hepatitis B, sedangkan untuk petugas kesehatan yang bekerja $<5$ tahun banyak yang memiliki pengetahuan baik, hal ini menguatkan teori tentang faktor-faktor yang mempengaruhi 
pengetahuan seseorang, yaitu tentang informasi dimana seseorang petugas kesehatan yang baru bekerja di RSUP Prof. R.D. Kandou dapat memperoleh pengetahuan yang baik lewat informasi, yaitu informasi kesehatan tentang Hepatitis B, sehingga informasi juga dapat mempengaruhi tingkat pengetahuan seseorang terhadap Hepatitis B.

\section{SIMPULAN}

Dari penelitian ini dapat ditarik simpulan bahwa:

1. Petugas kesehatan di RSUP Prof. R.D. Kandou memiliki pengetahuan yang baik terhadap penyakit Hepatitis B.

2. Pengetahuan terhadap penyakit Hepatitis B pada petugas kesehatan di RSUP Prof R.D. Kandou, tidak dipengaruhi oleh ada atau tidaknya mengikuti pelatihan tetapi dari pengalaman kerja dan juga melalui pendidikan formal.

\section{DAFTAR PUSTAKA}

1. Mohammad J, SoenartoSY, Oswari H, Arief S, Rosalina I, Mulyana NS. Buku ajar Gastroenterologi-Hepatologi. Jilid 1. Jakarta:Badan Penerbit IDAI; 2012. h. 296304, 356-358.

2. Centers for Disease Control and Prevention. Hepatitis B. Diakses pada 13 November 2013

darihttp://www.cdc.gov/hepatitis/hbv/pdfs/h epbgeneralfactsheet.pdf.

3. Rampengan TH. Penyakit infeksi tropik pada anak. Edisi 2. Jakarta: Penerbit Buku Kedokteran EGC; 2007. h.150-151

4. Simbolon AMA. Hepatitis B. Diakses pada 18 November 2013 darihttp://repository.usu.ac.id/bitstream/123 456789/22569/5/Chapter\%20I.pdf

5. Chan OK, Terence TL, Stephen SH, Leung TY. Deficient Knowledge on Hepatitis B Infection in Prevalence of Hepatitis B Surface Antigen Carriage in an Endemic Area. Oi Ka Chan et al. Hepatitis Research and Treatment; 2012.

6. Notoadmojo S. Pendidikan dan Perilaku Kesehatan. Jakarta: PT. Rineka Cipta; 2005. h. 122-124. 